\title{
TEMPORAL, SPATIAL AND HYDROGRAPHICAL DISTRIBUTION OF COPEPODS AT THE WESTERN EGYPTIAN MEDITERRANEAN COAST.
}

\author{
Fekry M. Abo-Senna ${ }^{1}$, Abdel-Kader M. Hassan ${ }^{1}$, Howida Y. Zakaria ${ }^{2}$, Hussein A. El- \\ Naggar ${ }^{1}$
}

1- Department of Zoology, Faculty of Science, Al-Azhar University (Boy), Cairo, Egypt. 2- National Institute of Oceanography and Fisheries, Alexandria, Egypt.

\begin{abstract}
At western Egyptian Mediterranean Coast, four cruises (spring 2008, summer 2008, winter 2009 and winter 2010) were carried out to study the temporal, spatial and hydrographical distribution of copepods. 129 copepod species were identified during the present study, dominated by Oithona nana, Calocalanus pavo and Nannocalanus minor. Spring was the most productive and diversified season. The abundance and diversity of copepods was homogeneous among the same seasons at successive two years. A comparison between the present data and that previously recorded in the Egyptian Mediterranean waters indicated large differences in records to the favor of the present work. Fifty five new recorded species of copepods were found in the Egyptian Mediterranean waters for the first time among them thirty two species seem to be recorded in the whole Mediterranean Sea for the first time.
\end{abstract}

Key Word: Mediterranean Sea, Temporal, spatial, hydrographical distribution, Migration, copepods,

\section{INTRODUCTION}

According to Lancelot et al., (2002), The Mediterranean Sea is one of the most oligotrophic semi-enclosed basins and its marine life is heavily threatened by habitat degradation mostly due to human activities. Halim (1990) mentioned that the marine environment of the Egyptian Mediterranean coast has been considerably impacted by two man-mad changes: the creation of a waterway between the Red and Mediterranean Seas (the Suez Canal) and the construction of the Aswan High Dam. Kimor (1972) declared that the Suez Canal is considered as a link and barrier in migration of planktonic organisms between the Red and Mediterranean Seas. The construction of the Aswan High Dam and subsequent abrupt curtailment of the seasonal outflow of nutrient-rich Nile water into the sea also caused dramatic changes in the biological and physico-chemical characteristics off the southeastern Mediterranean waters (Zakaria, 2006a). Evidently, planktonic migration is a continuous process (Abd El-Rahman, 2005), the migration process is increasing from south toward the north of the Suez Canal particularly after the disappearance of hydrological barriers from the canal pathway (Kimor, 1972) and the increasing salinity in the hole Levantine Basin after the high Aswan Dam Event (Por, 1978).

Copepods hold a key position in marine food webs as the major secondary producers of the world's oceans (Steinberg et al., 2002 and Walter and Boxshall, 2008). Herbivorous copepods can control different size classes of phytoplankton communities, and omnivorous and carnivorous copepods feed on micro- and meso-zooplankton including early developmental stages (Bennett, 2005). They are in turn controlled by predators from the macrozooplanktonic, micronektonic, and fish communities. For example, developmental stages of copepods constitute the principal prey of such small pelagic fish species as anchovies (Al-Mutairi, 2009). Schipp (2006) enumerated the benefits of using copepods in aquaculture, these benefits include: their superior nutritional value, high digestibility, movement patterns which trigger a strong feeding response in fish larvae, small size and simply the fact that they are part of the natural food chain for fish in the wild. Some investigator were successfully cultured copepods such as Olivotto et al. (2010); Cassiano et al., (2011); Ananth and Santhanam (2011) and Ananthi et al. (2011). 
As a consequence, the biodiversity and productivity of the southeast Levantine basin and Egyptian waters in particular have dramatically changed. Most investigations on zooplankton populations in Egyptian Mediterranean waters concerned with numerical abundance, seasonal distribution, and species composition in costal waters. Several studies on zooplankton distribution have been carried out in the Egyptian Mediterranean sea with difference of investigated sites along sea coast, some of them (El-Maghraby, 1965; Dowidar and ElMaghraby, 1970a \& b and 1973; Aboul-Ezz, 1994; Abdel-Aziz, 1997 and 2002; Hussein, 1997a and b; Abdel-Aziz and Aboul-Ezz, 2003; Zakaria 2006a, 2007 a and b, Zakaria $e t$ al., 2007; and El-Gindy et al., 2008). But, the offshore Egyptian Mediterranean waters have received a little attention (Hussein, 1977; Nour El-Din, 1987 and Zakaria, 2006b).

The present work aimed to follow up hydrographical distribution of copepod community in the Egyptian Mediterranean water, in addition to determination of its spatial and temporal distribution of recorded species.

\section{MATERIALS AND METHODS}

\section{1- The study area}

The study area lies between longitudes $25^{\circ}$ and $28.5^{\circ}$ and extending between latitude $31^{\circ}$ and $32.5^{\circ}$ (fig.1). The Egyptian waters are characterized by the presence of different water masses which converge and mix: the surface water mass of minimum salinity (38.6-38.8ppt) and maximum oxygen concentration $(>5.2 \mathrm{ml} / \mathrm{l})$ which is of Atlantic origin and extends 50 $150 \mathrm{~m}$ in depth; the intermediate water mass of maximum salinity (38.9-39.1 ppt) which extends below $150 \mathrm{~m}$ to about 300-400 m depth; and the deep waters which are of eastern Mediterranean origin (Said \& Eid, 1994). The surface water temperature of the study area varies $16.3-17.9^{\circ} \mathrm{C}$ in winter and $22-27.8^{\circ} \mathrm{C}$ in summer. Salinity values of the surface water range over 39-39.2 ppt through out the year (Zakaria, 2006b). pH values at Egyptian Mediterranean coast ranged between 7.98-8.44 in winter and 8.07-8.6 in summer. Dissolved oxygen ranged 4.13-5.32 $\mathrm{ml} / \mathrm{l}$ in winter and 4.83-5.71 $\mathrm{ml} / \mathrm{l}$ in summer (Hemaida et al., 2008).

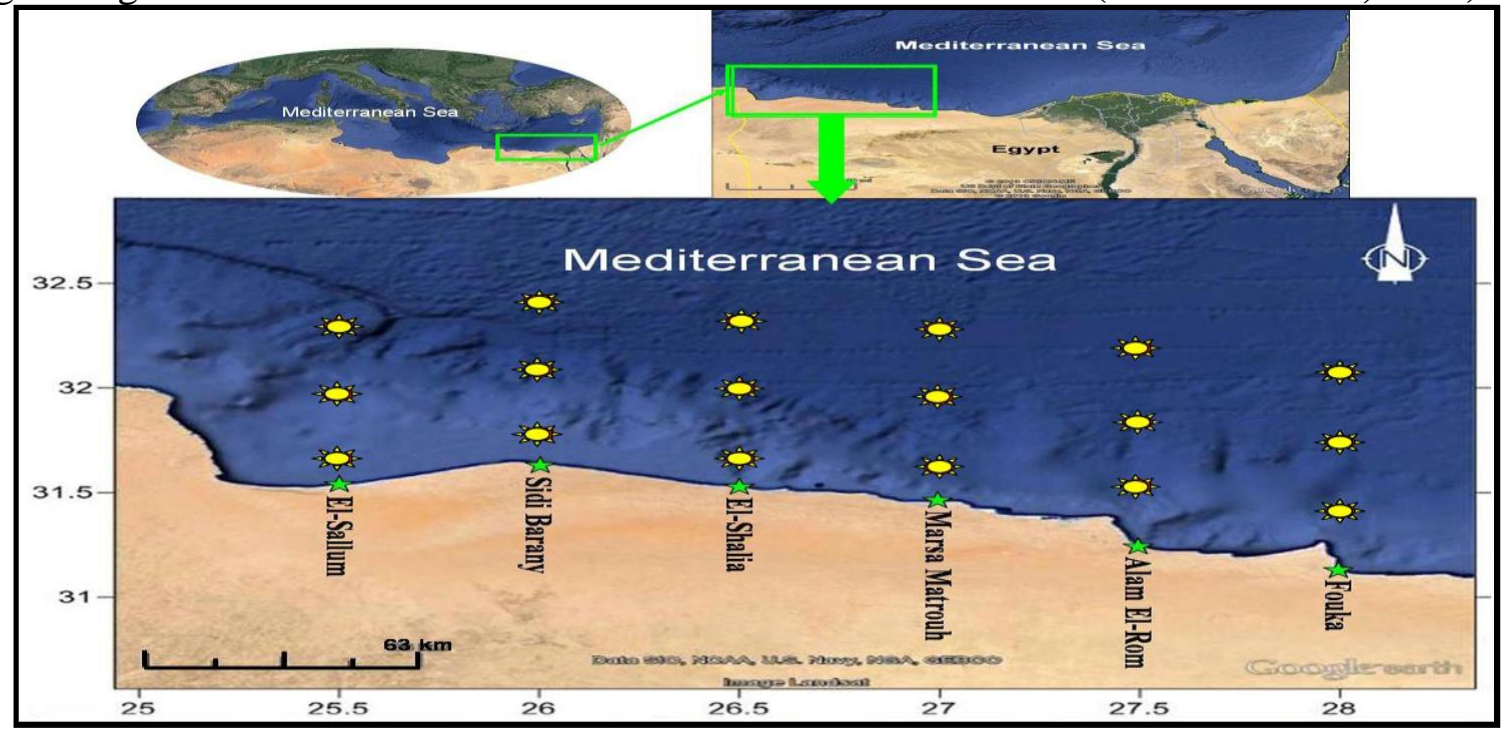

Figure (1): Map Showing the study area and the collecting stations in the Egyptian Mediterranean Sea.

\section{2- Samples collection}

Quantitative and qualitative investigations of copepod community in the study area were performed during four seasons namely spring 2008, summer 2008, winter 2009 and winter 2010. The study area was divided into six sectors. Three stations were investigated at each sector representing different depth zone (inshore neritic, offshore neritic and oceanic zone). The samples were collected by vertical hauls (from bottom to the surface) using standard 
plankton net of $55 \mu \mathrm{m}$ mesh and preserved in $4 \%$ neutral formalin solution and their volumes were concentrated to $100 \mathrm{ml}$. Three replicates of $3 \mathrm{ml}$ were transferred into a counting cell and each copepod was identified and counted under a binocular research microscope.

\section{3- Systematic: identification of samples}

The identification of collected copepods organisms was done according to some literatures such Rose (1933); Tregouboff \& Rose (1957); Edmondson et al. (1959); Boltovskoy (1999) and Conway et al. (2003). For confirmation of the identified species several data basis on the World Wide Web was consulted.

\section{4- Statistical analysis}

The standing crop of the total copepod community was calculated and expressed in number per cubic meter.

Species diversity was calculated according to Shannon and Weaver equation (1963).

$$
\mathrm{H}=\sum_{\mathrm{i}=1}^{\mathrm{n}} \mathrm{p}_{\mathrm{i}} \ln \mathrm{p}_{\mathrm{i}}
$$

Where: $\mathrm{pi}=\mathrm{n} / \mathrm{N}$ is the proportion of the number of individuals of species (n) to the total number of individuals $(\mathrm{N})$.

Richness was calculated according to Margalef's equation (1968).

$$
D=(S-I) / l n ~ N
$$

Where $\mathrm{D}=$ richness, $\mathrm{S}$ is the number of species and $\mathrm{N}$ is the total number of individuals.

\section{RESULT \\ 1- Copepod community:-}

Over the whole period, copepods were the main abundant and dominant zooplankton group along Eastern Mediterranean Sea in Egypt. The examination of the plankton samples collected from Egyptian Mediterranean water revealed that copepods represented about $74.14 \%$ (with an annual abundance of $699.3,609.7$ and 555.7 ind. $/ \mathrm{m}^{3}$ for inshore, offshore and oceanic zone, respectively) of the total zooplankton abundance. A total of 129 copepods species belong to 53 genera, 29 Families and 5 orders were identified during the present study. 71 calanoid species plus 10 cyclopoid, 9 harpacticoid, 39 Poecilostomatoid and only one Siphonostomatoid species were illustrated in table (1). Some recorded species were showed in plate (1)

Oithona nana was the main abundant and dominant species at all study period with an annual average of 56.8 ind. $/ \mathrm{m}^{3}$ ( $9.13 \%$ of the total adult copepods abundance), followed by Calocalanus pavo (41.8 ind. $/ \mathrm{m}^{3}, 6.7 \%$ of the total adult copepods abundance), Nannocalanus minor (38.86 ind. $/ \mathrm{m}^{3}, 6.25 \%$ of the total adult copepods), Clausocalanus arcuicornis, Paracalanus parvus, Oithona plumifera, Oithona similes, Subeucalanus crassus and Microsetella norvegica. While, there were 24 species (collectively $0.68 \%$ of the total adult copepods count) seen only one time during study period.

2- Ecological affinities and hydrographical distribution of recorded species in the Egyptian Mediterranean water and other adjacent water bodies:-

According to the available data, table (1) explains of Ecological affinities and the geographical distribution of recorded species in the Egyptian Mediterranean water and other adjacent water bodies. It is clear from this table; there are 55 copepods species were found in the Egyptian Mediterranean waters for the first time and about 32 species were recorded in the whole Mediterranean Sea for the first time.

The present result explain that about $74 \%$ of the total recorded species were previously recorded in the Mediterranean Sea, among them 56.5\% were recorded at Egyptian waters of Mediterranean in the previous studies. Figure (2) show the percentage of the origin of the recorded species in the Egyptian Mediterranean water and other adjacent water bodies. It is 
clear from this figure, $80.15 \%$ of the recorded species were previously recorded in Atlantic ocean, $77 \%$ in Pacific ocean, $74 \%$ in Indian ocean and $63.4 \%$ were recorded in the Red Sea.

Table (1): Ecological affinities and geographical distribution of recorded copepods species. AO = Atlantic Ocean, $\mathrm{PO}=$ Pacific Ocean, $\mathrm{IO}=$ Indian Ocean, $\mathrm{RS}=$ Red Sea, MS. = Mediterranean Sea and EM = Egyptian Mediterranean Sea, PS. = Present Study.

\begin{tabular}{|c|c|c|c|c|c|c|c|}
\hline $\begin{array}{l}\text { Phylum: Arthropoda } \\
\text { Subphylum: Crustacea }\end{array}$ & & eogi & aph & cal & istri & utio & \\
\hline Subclass: Copepoda & AO. & PO. & IO. & RS. & MS. & EM. & PS. \\
\hline $\begin{array}{l}\text { Order: Calanoida } \\
\text { Family: Calanidae }\end{array}$ & & & & & & & \\
\hline Calanus helgolandicus (Claus, 1863) & + & + & & & + & & + \\
\hline Canthocalanus pauper (Giesbrecht, 1888) & & + & + & + & + & & + \\
\hline Cosmocalanus darwinii (Lubbock, 1860) & + & + & + & + & + & & + \\
\hline Mesocalanus tenuicornis (Dana, 1849) & + & + & + & + & + & + & + \\
\hline Nannocalanus minor (Claus, 1863) & + & + & + & + & + & + & + \\
\hline Neocalanus gracilis (Dana, 1849) & + & + & + & & + & + & + \\
\hline Neocalanus plumchrus (Marukawa, 1921) & & + & & + & & & + \\
\hline Neocalanus robustior (Giesbrecht, 1888) & + & + & & + & + & + & + \\
\hline Calanus sp. & & & & & & & + \\
\hline Family: Eucalanidae & & & & & & & \\
\hline Pareucalanus attenuatus (Dana, 1849) & + & + & + & + & + & + & + \\
\hline Subeucalanus crassus (Giesbrecht, 1888) & + & + & + & + & + & + & + \\
\hline Subeucalanus monachus (Giesbrecht, 1888) & + & & + & & + & + & + \\
\hline Subeucalanus subcrassus (Giesbrecht, 1888) & + & + & + & + & & & + \\
\hline Family: Paracalanidae & & & & & & & \\
\hline Acrocalanus gibber Giesbrecht, 1888 & & + & + & + & + & & + \\
\hline Calocalanus contractus Farran, 1926 & + & + & & & + & + & + \\
\hline Calocalanus pavo (Dana, 1852) & + & + & + & + & + & + & + \\
\hline Calocalanus styliremis Giesbrecht, 1888 & + & + & + & + & + & + & + \\
\hline Ischnocalanus plumulosus (Claus, 1863) & + & + & + & + & + & + & + \\
\hline Mecynocera clausi Thompson I.C., 1888 & + & + & + & + & + & + & + \\
\hline Paracalanus parvus (Claus, 1863) & + & + & + & + & + & + & + \\
\hline Family: Clausocalanidae & & & & & & & \\
\hline Clausocalanus arcuicornis (Dana, 1849) & + & + & + & + & + & + & + \\
\hline Clausocalanus furcatus (Brady, 1883) & + & + & + & + & + & + & + \\
\hline Clausocalanus ingens Frost \& Fleminger, 1968 & + & & + & & & & + \\
\hline Clausocalanus pergens Farran, 1926 & + & & + & + & + & + & + \\
\hline Clausocalanus sp. & & & & & & & + \\
\hline Pseudocalanus elongatus (Boeck, 1865) & + & + & & & + & & + \\
\hline Family: Aetideidae & & & & & & & \\
\hline Aetideus armatus (Boeck, 1872) & + & + & + & & & & + \\
\hline Aetideus bradyi Scott A., 1909 & + & + & + & & & & + \\
\hline Aetideus giesbrechti Cleve, 1904 & + & + & + & & + & + & + \\
\hline Family: Scolecitrichidae & & & & & & & \\
\hline Scolecithricella bradyi (Giesbrecht, 1888) & + & + & + & & + & + & + \\
\hline Family: Euchaetidae & & & & & & & \\
\hline Euchaeta acuta Giesbrecht, 1892 & + & + & + & & + & + & + \\
\hline Euchaeta marina (Prestandrea, 1833) & + & + & + & + & + & + & + \\
\hline Euchaeta media Giesbrecht, 1888 & + & + & + & & & & + \\
\hline Euchaeta sp. & & & & & & & + \\
\hline Family: Phaennidae & & & & & & & \\
\hline Phaenna spinifera Claus, 1863 & + & + & + & + & + & + & + \\
\hline Xanthocalanus sp. & & & & & & & + \\
\hline Family: Centropagidae & & & & & & & \\
\hline Centropages abdominalis Sato, 1913 & & + & & & & & + \\
\hline Centropages aucklandicus Kramer, 1895 & + & + & & & + & + & + \\
\hline Centropages bradyi Wheeler, 1900 & + & + & & & + & & + \\
\hline Centropages elongatus Giesbrecht, 1896 & & + & + & + & & & + \\
\hline Centropages kroyeri Giesbrecht, 1893 & + & & & + & + & + & + \\
\hline Centropages tenuiremis Thomp. \& Scott 1903 & & + & + & & & & + \\
\hline Centropages violaceus (Claus, 1863) & + & + & + & + & + & + & + \\
\hline Isias clavipes Boeck, 1865 & + & & & & + & + & + \\
\hline Family: Temoridae & & & & & & & \\
\hline Temora discaudata Giesbrecht, 1889 & + & + & + & + & + & & + \\
\hline Temora stylifera (Dana, 1849) & + & & + & + & + & + & + \\
\hline Temora turbinata (Dana, 1849) & + & + & + & + & + & & + \\
\hline Family: Lucicutiidae & & & & & & & \\
\hline Lucicutia flavicornis (Claus, 1863) & + & + & + & + & + & + & + \\
\hline Lucicutia longicornis (Giesbrecht, 1889) & + & & & & & & + \\
\hline Lucicutia ovalis (Giesbrecht, 1889) & + & + & + & + & + & + & + \\
\hline
\end{tabular}




\begin{tabular}{|c|c|c|c|c|c|c|c|}
\hline $\begin{array}{l}\text { Family: Heterorhabdidae } \\
\text { Heterorhabdus papilliger (Claus, 1863) } \\
\text { Family: Metridinidae }\end{array}$ & + & + & + & + & + & + & + \\
\hline Pleuromamma abdominalis (Lubbock, 1856) & + & + & + & + & + & + & + \\
\hline Pleuromamma borealis Dahl F., 1893 & + & + & & & + & & + \\
\hline Pleuromamma gracilis Claus, 1863 & + & + & + & + & + & + & + \\
\hline Pleuromamma piseki Farran, 1929 & + & & + & & & & + \\
\hline Pleuromamma robusta (Dahl F., 1893) & + & + & + & + & + & + & + \\
\hline Pleuromamma xiphias (Giesbrecht, 1889) & + & + & + & & + & + & + \\
\hline Family: Augaptilidae & & & & & & & \\
\hline $\begin{array}{l}\text { Haloptilus longicornis (Claus, 1863) } \\
\text { Family: Acartiidae }\end{array}$ & + & + & + & + & + & + & + \\
\hline Acartia (Acartiura) clausi Giesbrecht, 1889 & + & + & + & & + & + & + \\
\hline Acartia (Acartia) danae Giesbrecht, 1889 & + & + & + & + & + & + & + \\
\hline Acartia (Acartiura) longiremis (Lilljeb., 1853) & + & + & & & + & + & + \\
\hline $\begin{array}{l}\text { Acartia (Acartia) negligens Dana, } 1849 \\
\text { Acartia } \text { sp. }\end{array}$ & + & + & + & + & + & + & $\begin{array}{l}+ \\
+\end{array}$ \\
\hline Family: Candaciidae & & & & & & & \\
\hline Candacia bipinnata (Giesbrecht, 1888) & + & + & + & & + & & + \\
\hline Candacia bispinosa (Claus, 1863) & + & + & + & + & + & + & + \\
\hline Candacia bradyi Scott A., 1902 & & + & + & & & & + \\
\hline Candacia curta (Dana, 1849) & + & + & + & + & & & + \\
\hline Candacia longimana (Claus, 1863) & + & + & + & + & + & + & + \\
\hline Candacia simplex (Giesbrecht, 1889) & + & + & + & + & + & + & + \\
\hline Candacia truncata (Dana, 1849) & & + & + & + & & & + \\
\hline Candacia sp. & & & & & & & + \\
\hline Undefined calanoid species & & & & & & & + \\
\hline Order: Cyclopoida & & & & & & & \\
\hline Family: Oithonidae & & & & & & & \\
\hline Dioithona rigida Giesbrecht, 1896 & & & + & + & + & & + \\
\hline Oithona fallax Farran, 1913 & + & + & + & + & + & & + \\
\hline Oithona linearis Giesbrecht, 1891 & + & & & & + & + & + \\
\hline Oithona nana Giesbrecht, 1893 & + & + & + & + & + & + & + \\
\hline Oithona plumifera Baird, 1843 & + & + & + & + & + & + & + \\
\hline Oithona robusta Giesbrecht, 1891 & + & + & + & + & + & & + \\
\hline Oithona setigera setigera Dana, 1852 & + & + & + & + & + & & + \\
\hline Oithona similis Claus, 1866 & + & + & + & + & + & + & + \\
\hline Oithona tenuis Rosendorn, 1917 & + & + & + & + & + & & + \\
\hline Family: Cyclopoida incertae sedis & & & & & & & \\
\hline Pachos punctatum (Claus, 1863) & + & + & + & + & + & + & + \\
\hline Order: Harpacticoida & & & & & & & \\
\hline Family: Euterpinidae & & & & & & & \\
\hline Euterpina acutifrons (Dana, 1847) & + & + & + & + & + & + & + \\
\hline Family: Peltidiidae & & & & & & & \\
\hline Goniopsyllus rostratus Brady, 1883 & + & + & + & + & + & + & + \\
\hline Family: Ectinosomatidae & & & & & & & \\
\hline Microsetella norvegica (Boeck, 1865) & + & + & + & + & + & + & + \\
\hline Microsetella rosea (Dana, 1847$)$ & + & + & + & + & + & + & + \\
\hline Family: Miraciidae & & & & & & & \\
\hline Macrosetella gracilis (Dana, 1847) & + & + & + & + & + & + & + \\
\hline Miracia sp. & & & & & & & + \\
\hline Family: Ameiridae & & & & & & & \\
\hline Nitokra lacustris (Shmankevich, 1875) & + & & & & + & + & + \\
\hline Family: Canthocamptidae & & & & & & & \\
\hline Canthocampatus sp. & & & & & & & + \\
\hline Undefined harpacticoid species & & & & & & & + \\
\hline Order: Siphonostomatoida & & & & & & & \\
\hline Family: Rataniidae & & & & & & & \\
\hline Ratania flava Giesbrecht, 1893 & + & + & + & + & + & & + \\
\hline Order: Poecilostomatoida & & & & & & & \\
\hline Family: Lubbockiidae & & & & & & & \\
\hline Lubbockia squillimana Claus, 1863 & + & + & + & + & + & + & + \\
\hline Family: Oncaeidae & & & & & & & \\
\hline Monothula subtilis (Giesbrecht, 1893 ["1892"]) & + & + & & + & + & + & + \\
\hline Oncaea atlantica Shmeleva, 1967 & + & & + & + & + & & + \\
\hline Oncaea lacinia Heron, Engl. \& Damkaer, 1984 & + & + & & & & & + \\
\hline Oncaea media Giesbrecht, 1891 & + & + & + & + & + & + & + \\
\hline Oncaea mediterranea (Claus, 1863) & + & + & + & + & + & + & + \\
\hline Oncaea venusta Philippi, 1843 & + & + & + & + & + & + & + \\
\hline Spinoncaea ivlevi (Shmeleva, 1966) & + & & + & + & + & & + \\
\hline Triconia conifera (Giesbrecht, 1891) & + & + & + & + & + & + & + \\
\hline Triconia minuta (Giesbrecht, 1893 ["1892"]) & + & + & + & + & + & + & + \\
\hline Triconia similis (Sars G.O., 1918) & + & + & + & + & + & + & + \\
\hline Oncaea sp. & & & & & & & \\
\hline Family: Sapphirinidae & & & & & & & \\
\hline
\end{tabular}




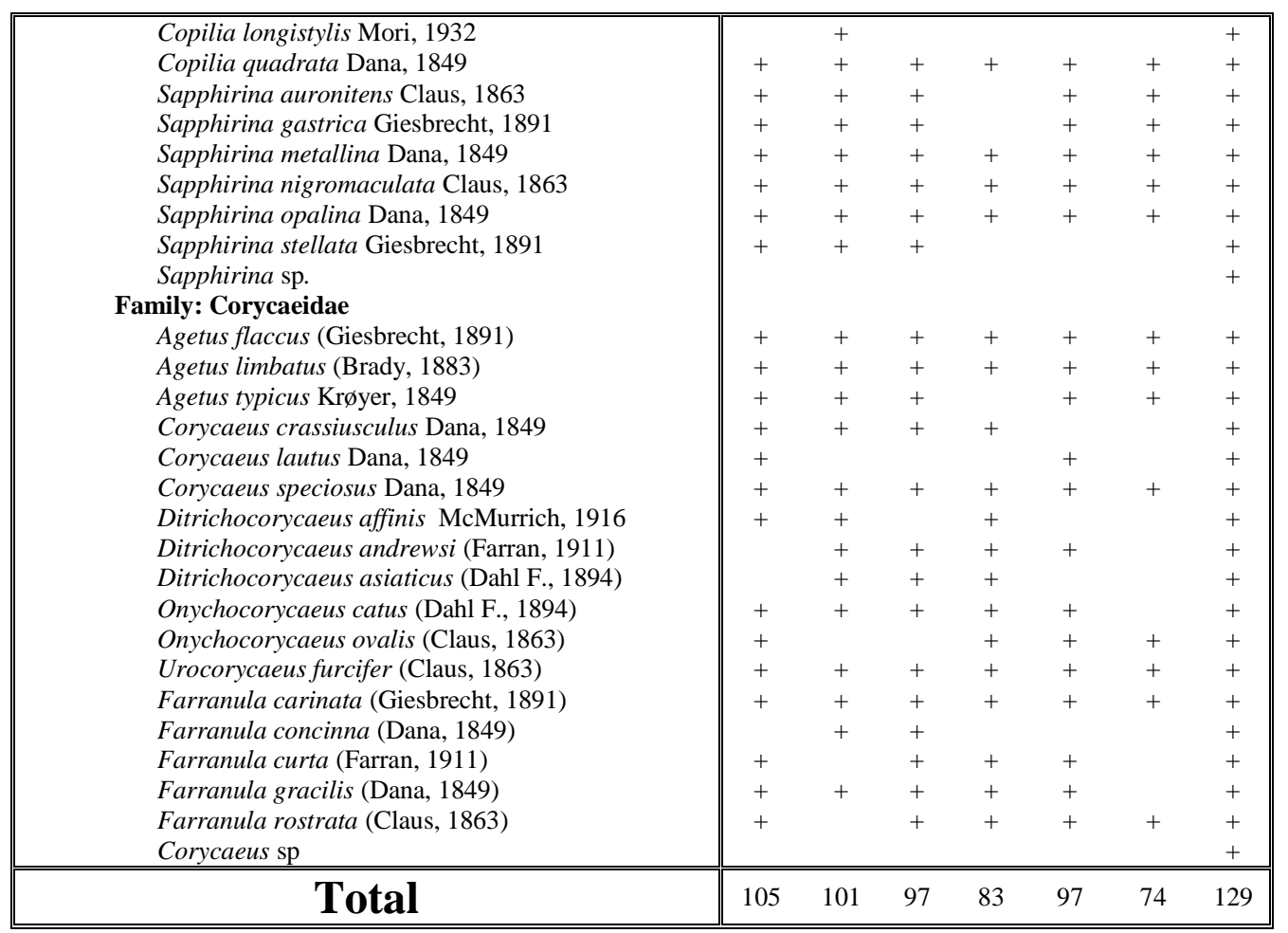

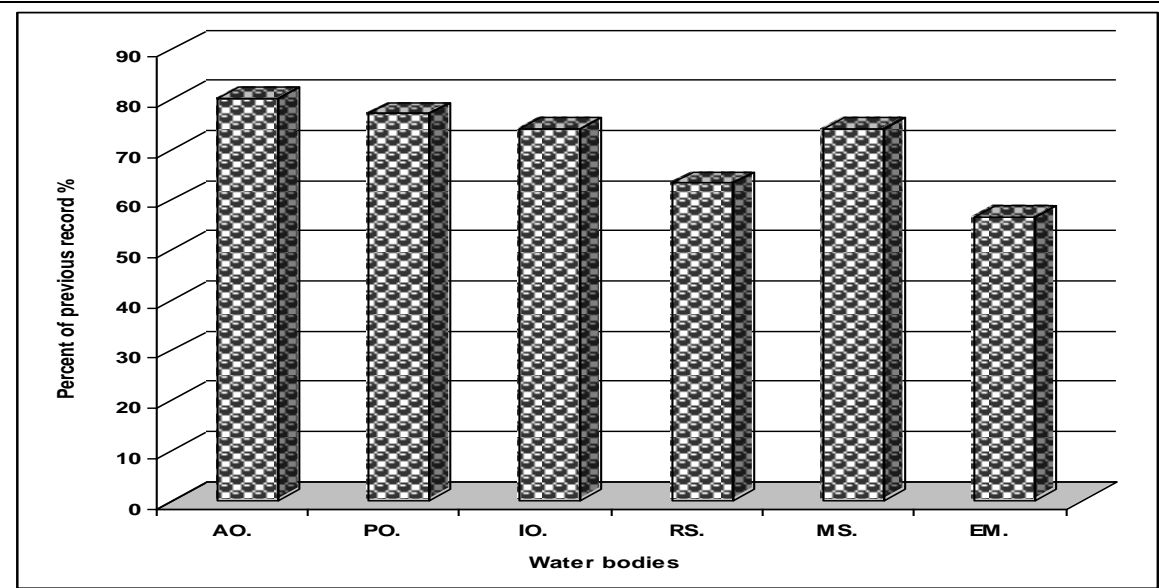

Fig. (2): The percentage of the origin of the recorded copepod species in the Egyptian Mediterranean water and other adjacent water bodies. $\mathrm{AO}=$ Atlantic Ocean, $\mathrm{IO}=$ Indian Ocean, $\mathrm{PO}=$ Pacific Ocean, $\mathrm{RS}=$ Red Sea, MS = Mediterranean Sea and EMS = Egyptian Mediterranean Sea.

\section{3- Temporal distribution of copepods species:-}

Figures (3 and 4) show of the temporal variations of copepod abundance between investigated seasons at different zones. According to the figure (3), copepods are highly abundance in spring season (40.2\% of the total copepods count). In spring season, Oithona nana was the highest abundant species with an average abundance of $\left(92.6 \mathrm{ind} . / \mathrm{m}^{3}\right)$ followed by Oithona plumifera $\left(45.1\right.$ ind. $\left./ \mathrm{m}^{3}\right)$ and Calocalanus pavo $\left(42.8 \mathrm{ind} . / \mathrm{m}^{3}\right)$. Copepodite stages constituted about $39 \%$ of the total copepods count, while nauplii larvae of copepods represented $25.4 \%$ of the total recorded copepods count. The second abundant season of copepods was summer held about $36.7 \%$ of the total recorded copepods. The abundant species were Nannocalanus minor (with an average of $62.1 \mathrm{ind} . / \mathrm{m}^{3}$ ), followed by Calocalanus pavo $\left(60.5\right.$ ind. $\left./ \mathrm{m}^{3}\right)$ then Oithona nana $\left(48\right.$ ind.$\left./ \mathrm{m}^{3}\right)$. Copepodite stages were constituted about $39.7 \%$ of the total copepods count, while nauplii of copepods represented $37.2 \%$ of the total copepods count in summer season. The later season was winter 2009, copepods constituted about $23.1 \%$ of the total copepods abundance. Farranula rostrata with an aaverage abundance of $\left(32.4\right.$ ind. $\left./ \mathrm{m}^{3}\right)$, Oithona nana $\left(29.73\right.$ ind. $\left./ \mathrm{m}^{3}\right)$ and Clausocalanus arcuicornis $\left(27.43 \mathrm{ind} . / \mathrm{m}^{3}\right)$ were the highest abundant species in this season. In winter, copepodite stages 
were represented about $36.2 \%$ of the total copepods count, while nauplii larvae of copepods represented $39.1 \%$ of the total recorded copepods count in this season.
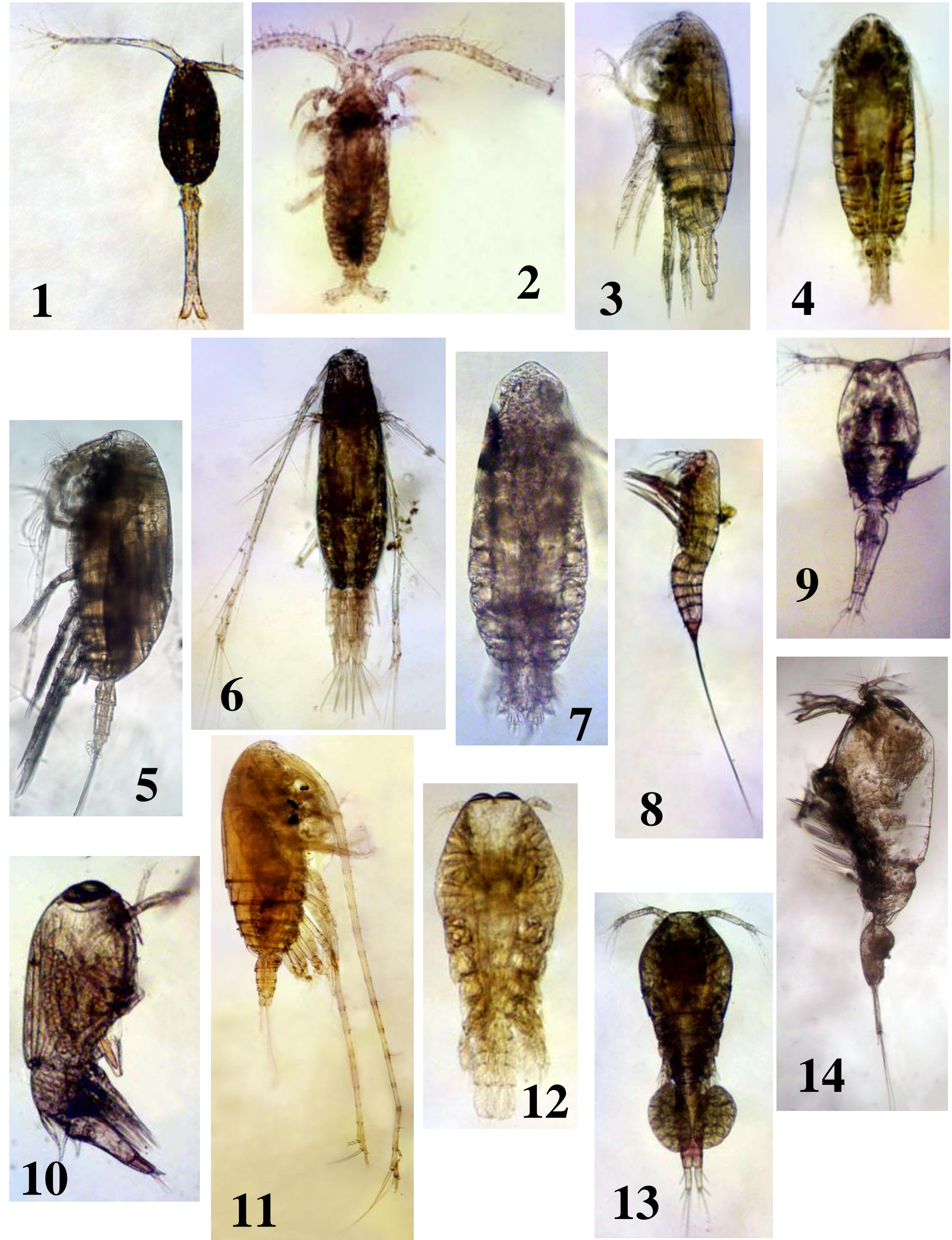

Plate (1): Some dominant copepods were recorded in the Egyptian Mediterranean water. 1- Oithona nana, 2 Calocalanus pavo, 3- Nannocalanus minor, 4- Clausocalanus arcuicornis, 5- Paracalanus parvus, 6Acartia negligens, 7- Subeucalanus crassus, 8- Microsetella norvegica, 9- Oncaea mediterranea, 10Farranula rostrata, 11- Neocalanus gracilis, 12- Sapphirina metallina, 13- Oncaea venusta, 14Agetus flaccus. 


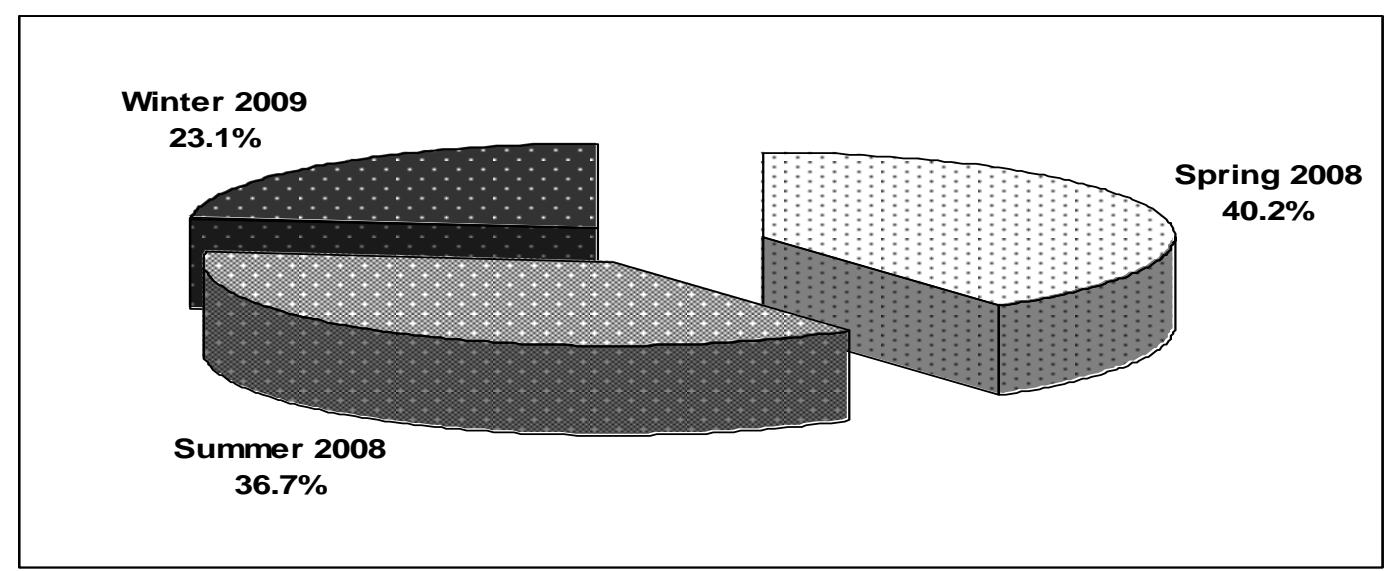

Figure (3): The percentage of the total recorded copepods abundance among different investigated seasons in the Egyptian Mediterranean water.

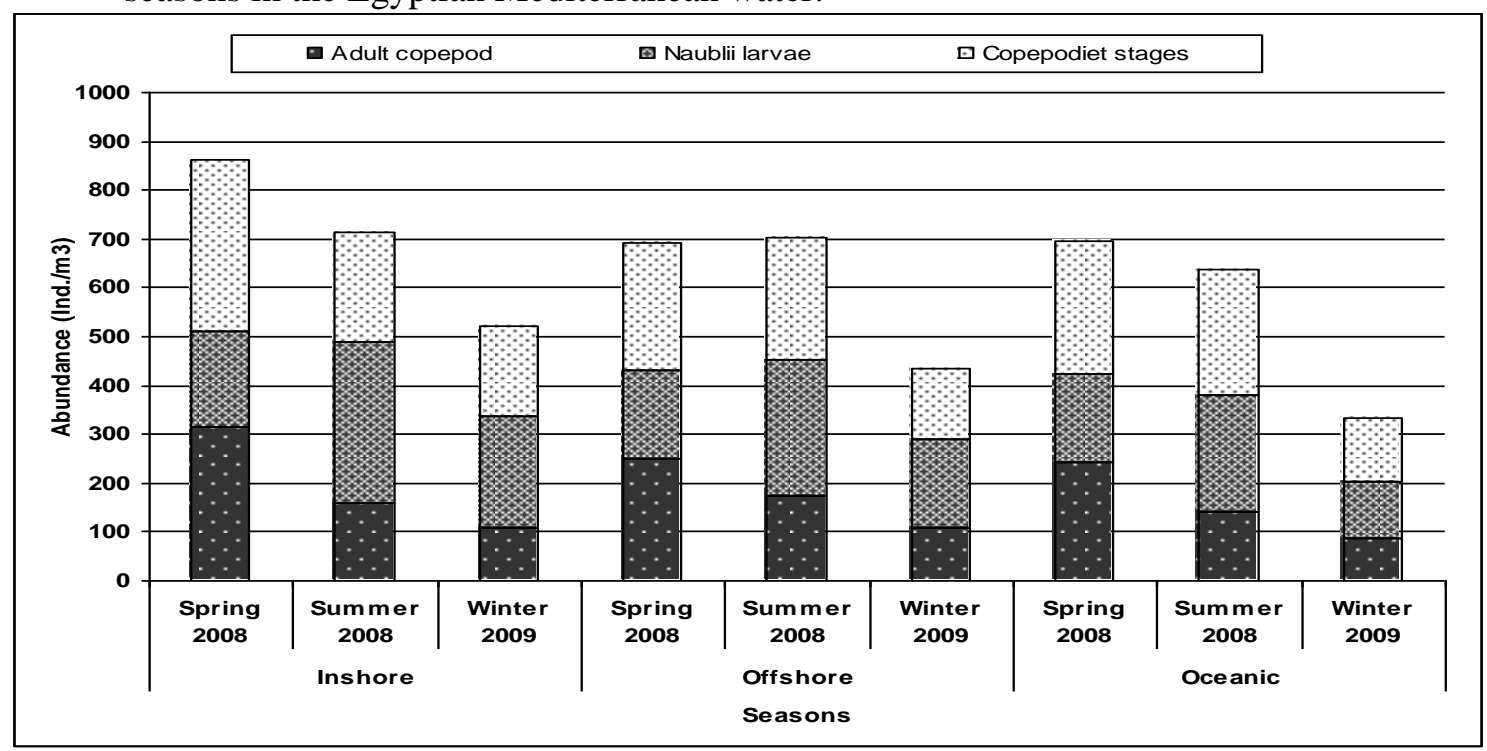

Figure (4): The average abundance of the total recorded copepods among different investigated seasons at different zones in the Egyptian Mediterranean water.

At the inshore nertic zone, spring ( $41.1 \%$ of the total average copepods count) is the more productive season followed by summer (34\%) then winter (24.9). While, summer $(38.4 \%$ of the total average copepods count) and spring (37.8\%) seasons have the highly average abundance of copepods at offshore zones and winter (23.8\%) has the poorest abundance. Also, spring ( $41.7 \%$ of the total average copepods count) is the more productive season at oceanic zone followed by summer (38.3\%) then winter (20\%). count at inshore and oceanic zones (fig. 4). From over view on the present result, nubilius larvae and copepodite stages were inversely proportional to the adult copepods, where they increased when adult copepods decreased and vice versa.

\section{4-Spatial distribution of copepods species:-}

Figures (5 and 6) show the spatial distribution of copepods in the Egyptian Mediterranean waters. According to this data, the total copepods abundance was equally distributed among different investigated sectors. Fouka (22.3\% of the total recorded copepods) was the highly productive sector, followed by Elshalia (18.2\%), Allam Elroum (16.6\%). While, the low productive sectors was Elsallom (10.9\%) and Sidi Brani and Marsa Matrouh have the same abundance $(16 \%)$ of the total recorded copepods.

The copepods abundance in the Egyptian Mediterranean Water varied greatly from sector to another at different zones. For all combined sectors, the copepod abundance show high four 
peaks (Fig. 5). The first peak occurred in Fouka sector at inshore zone with an annual average of 1132 ind. $/ \mathrm{m}^{3}$, the second in Marsa Matrouh at inshore zone with an annual average of 840 ind $/ \mathrm{m}^{3}$, the third in Fouka sector at offshore zone with an annual average of $767 \mathrm{ind} . / \mathrm{m}^{3}$, and the later one in Elshalia at inshore zone with an annual average of 738 ind. $/ \mathrm{m}^{3}$. The small peaks occurred in Elsallom sector at inshore zone (349 ind. $/ \mathrm{m}^{3}$ annual average) and Marsa Matrouh sector at oceanic zone with an annual average of $375 \mathrm{ind} . / \mathrm{m}^{3}$.

Also, the spatial distribution of copepods life stages along Egyptian Mediterranean water were equally distributed among sectors. It is clear from the figure (6), Marsa Matrouh sector at inshore zone had the highest naupilius larvae abundance (with an annual average 416.7 $\mathrm{ind} / \mathrm{m}^{3}$ ) followed by Fouka at inshore zone (with an annual average $349.7 \mathrm{ind} / \mathrm{m}^{3}$ ). While, the highest abundance of copepodite stages was occurred in Fouka at inshore zone (with an annual average $495 \mathrm{ind} / \mathrm{m}^{3}$ ), followed by Fouka at offshore zone (with an annual average 304 ind $/ \mathrm{m}^{3}$ ). Adult copepods abundance was high in Fouka sector at inshore zone with an annual average of 287.3 ind. $/ \mathrm{m}^{3}$. followed by Elshalia at inshore zone with an annual average 252 ind $/ \mathrm{m}^{3}$.

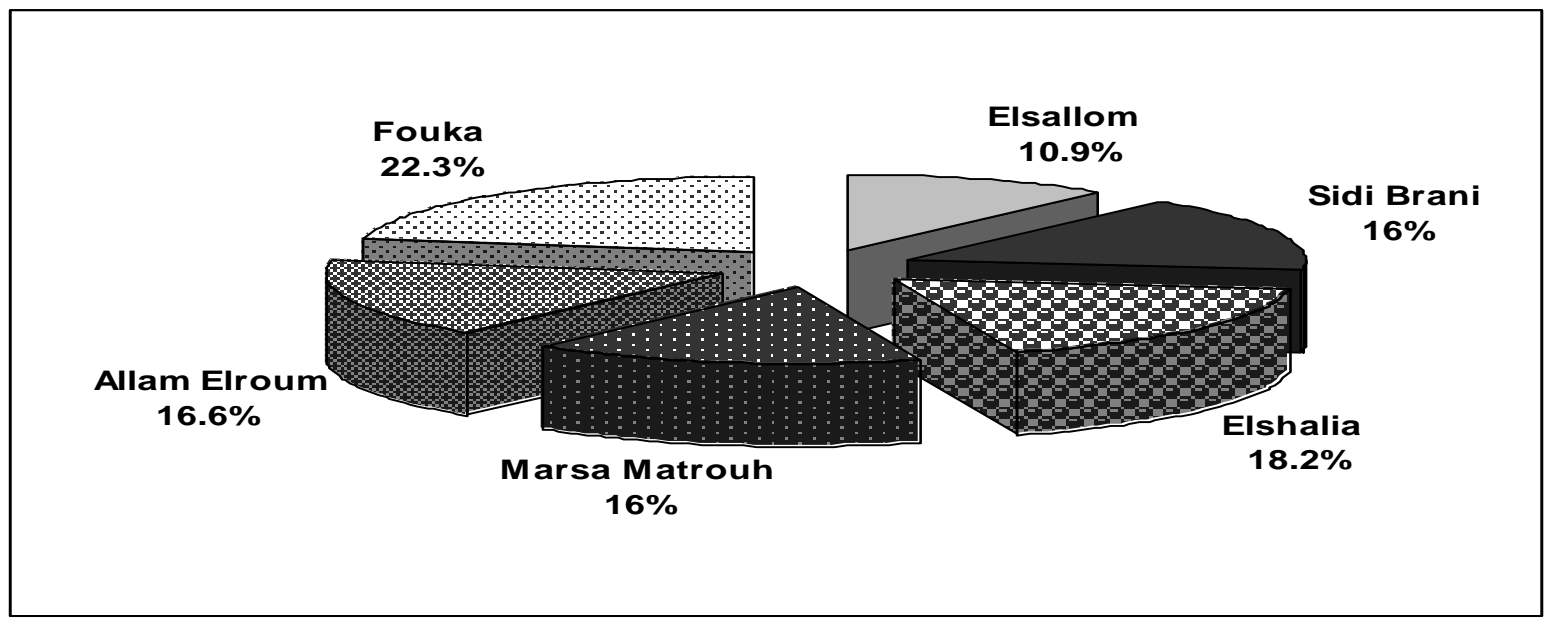

Figure (5): Spatial distribution of copepods between investigated sectors in the Egyptian Mediterranean waters.

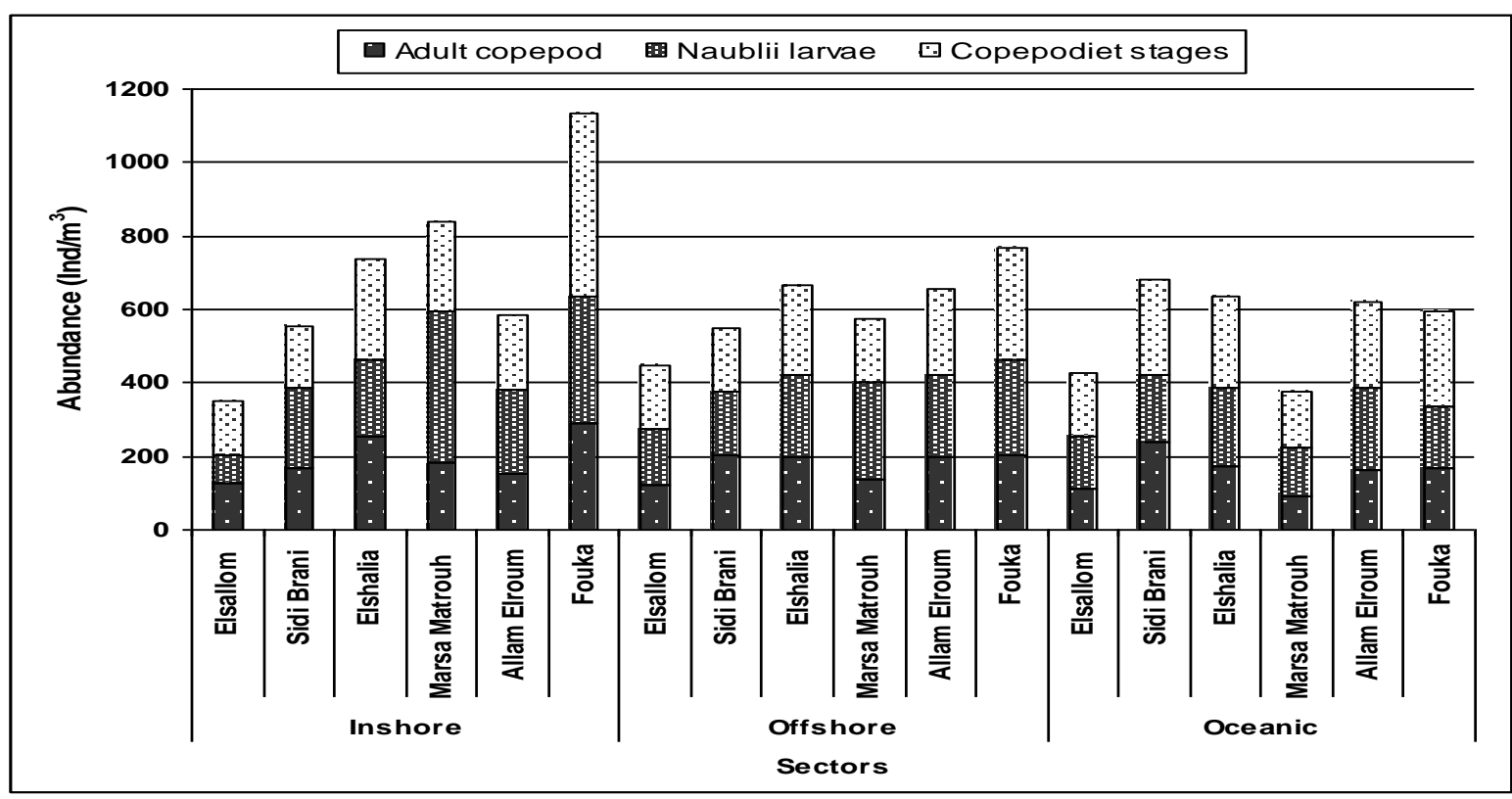

Figure (6): The annual average abundance of the total recorded copepods among different investigated seasons at different zones in the Egyptian Mediterranean water. 


\section{5- Diversity of copepods in the Egyptian Mediterranean Sea:-}

A total of 129 copepods species were identified in the Egyptian Mediterranean water during this study. The variations of copepods species diversity at study sectors were represented in figure (7). According to this figure, the greatest number of species occurred in Sidi Brani sector ( 86 species), followed by Elshalia sector ( 81 species), Fouka (79 species) and Elsalom (75 species) while the minimum abundance was recorded at Marsa Matrouh sector (60 species), followed by Allam Elroum (69 species).

It is clear from the figure (8), spring 2008 is the highest copepod diversified season in the present study, where it held 95 species. While, winter 2009 was considered as the lowest season held copepods species (70 species). Summer 2008 season held in this study about 85 species of copepods.

In this study, copepods were reached their highest diversity value (63 species) at Sidi Brani sector in spring 2008, followed by Elshalia sector in the same season (58 species). While, the lowest value of diversity were recorded at Marsa Matrouh sector (23 species) in winter 2009, followed by Elsalom sector ( 29 species) in the same season.

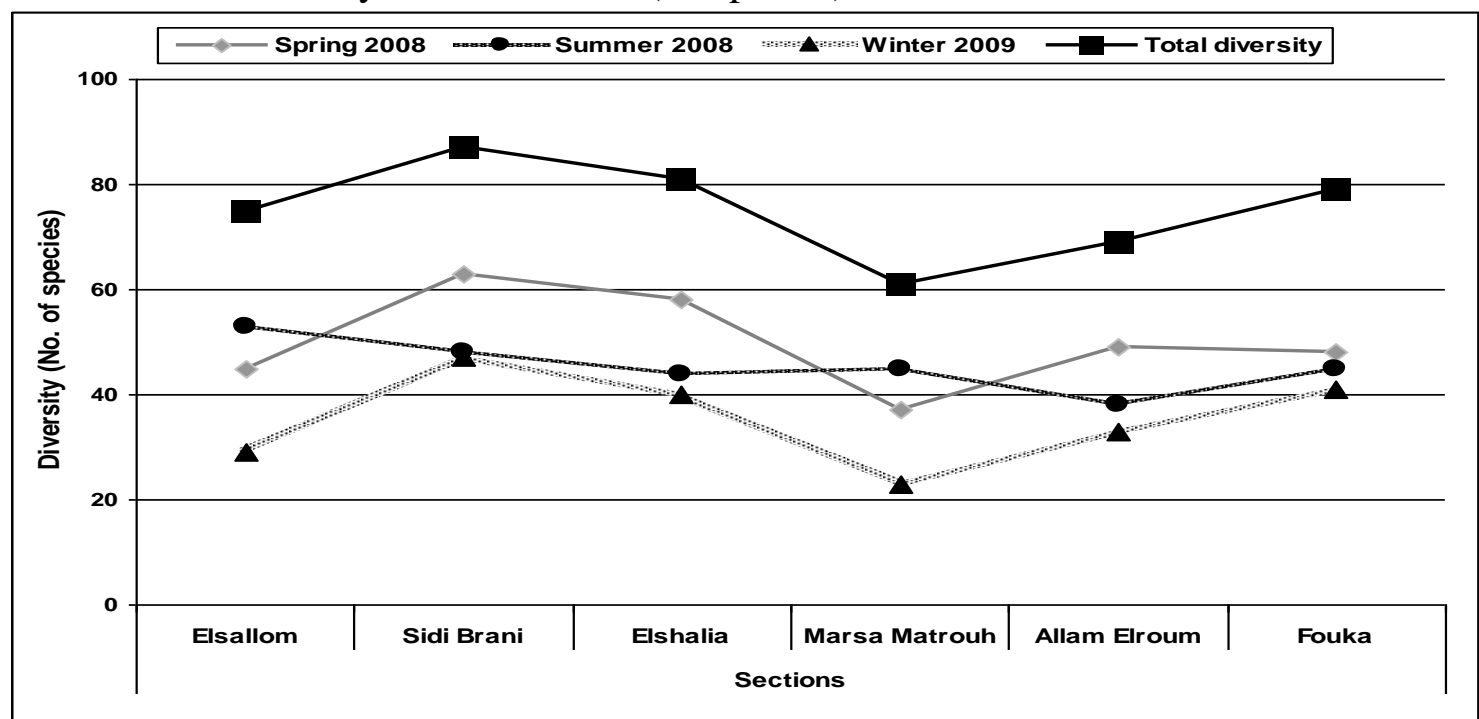

Figures (7): The diversity of the total copepods at different investigated seasons in the Egyptian Mediterranean water.

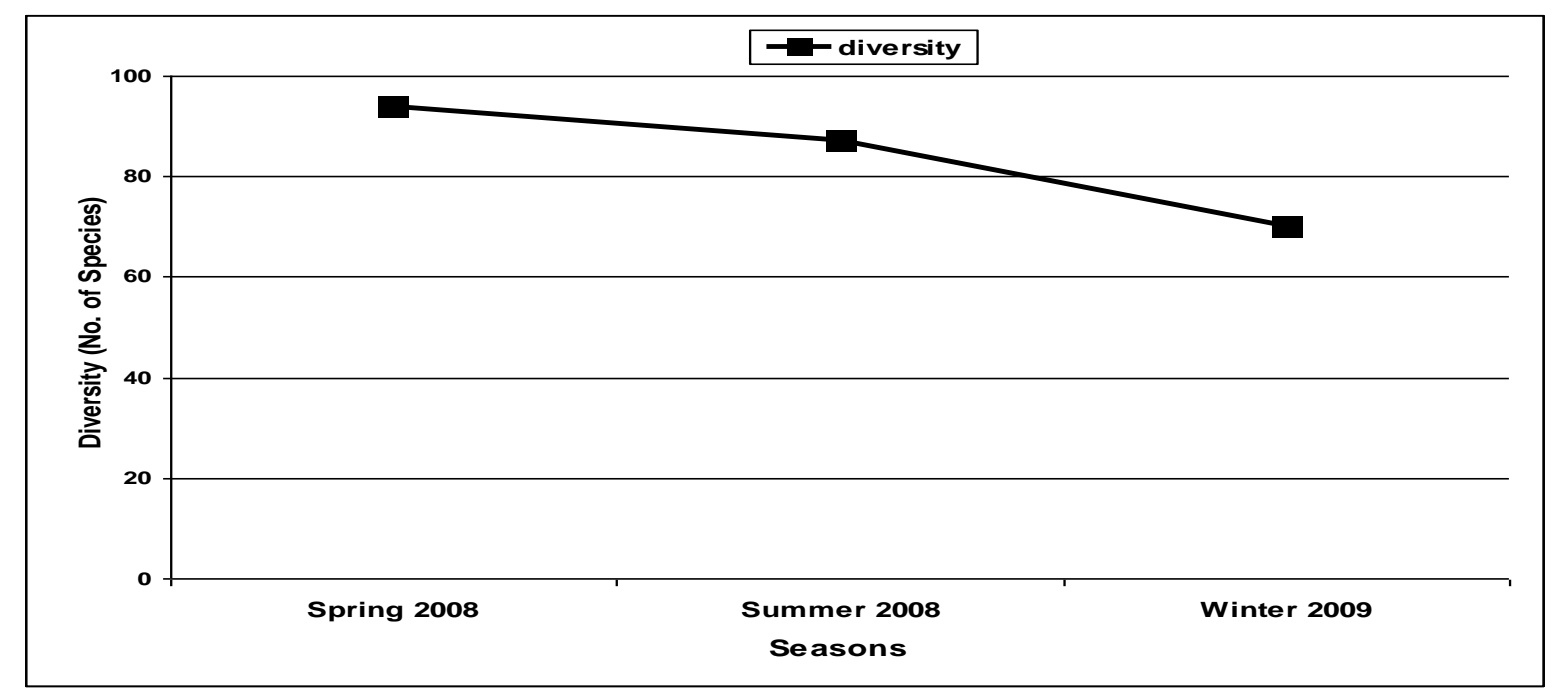

Figures (8): Te diversity of the total copepods at different investigated sectors and seasons in the Egyptian Mediterranean water. 


\section{6- Comparative study of the copepods abundance and diversity in the same season between successive two years:}

Comparison of the copepods abundance and diversity in winter season between successive two years 2009 and 2010 was studied and showed in figure (9 and 10). The average copepods abundance was decreased from winter 2009 to winter 2010 at all surveyed zone. Where, the average abundance of copepod at inshore zone was 521.8 and $424.3 \mathrm{ind} / \mathrm{m}^{3}$ for winter 2009 and 2010 respectively, at offshore zone copepods recorded average abundance $434.7 \mathrm{ind} . / \mathrm{m}^{3}$ for winter 2009 and $343.8 \mathrm{ind} . / \mathrm{m}^{3}$ for winter 2010 , while the average abundance of copepod at oceanic zone was 332.6 and $302.6 \mathrm{ind} / \mathrm{m}^{3}$ for winter 2009 and 2010 respectively. The variation of abundance values that were obtained from winter 2009 and winter 2010 was attributed to increasing of copepodite stage density in winter 2009 (average at all zones of 460 ind. $\left./ \mathrm{m}^{3}\right)$ than winter $2009\left(311.1\right.$ ind. $\left./ \mathrm{m}^{3}\right)$ and copepod naulii in winter 2009 (523.2 ind. $\left./ \mathrm{m}^{3}\right)$ than winter $2010\left(408.2 \mathrm{ind} . / \mathrm{m}^{3}\right)$, while adult copepods densities were fluctuated within narrow rang at all sectors between two investigated seasons.

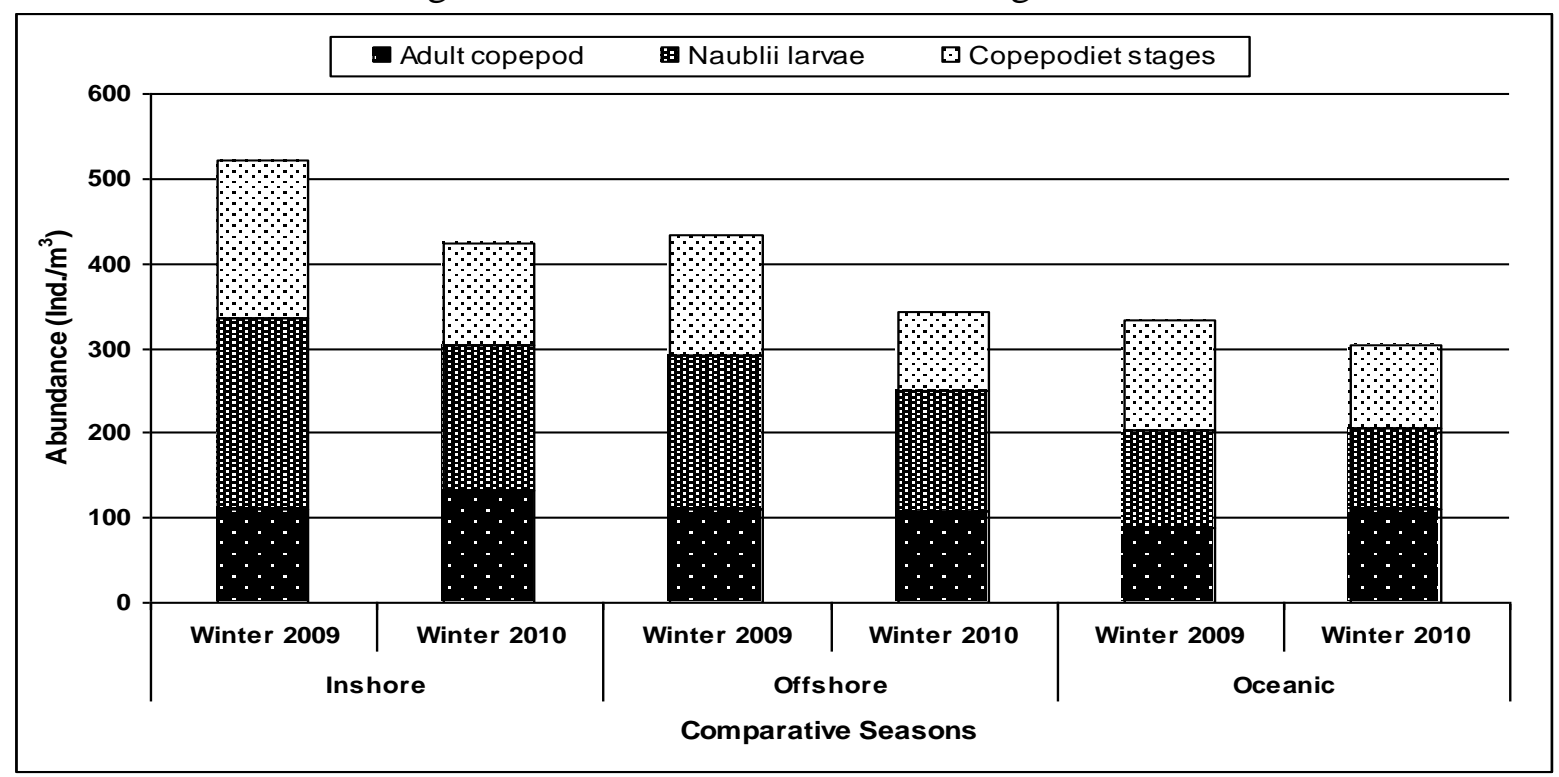

Figure (9): The average copepodsabundance in winter season between successive two years 2009 and 2010 at all surveyed zones.

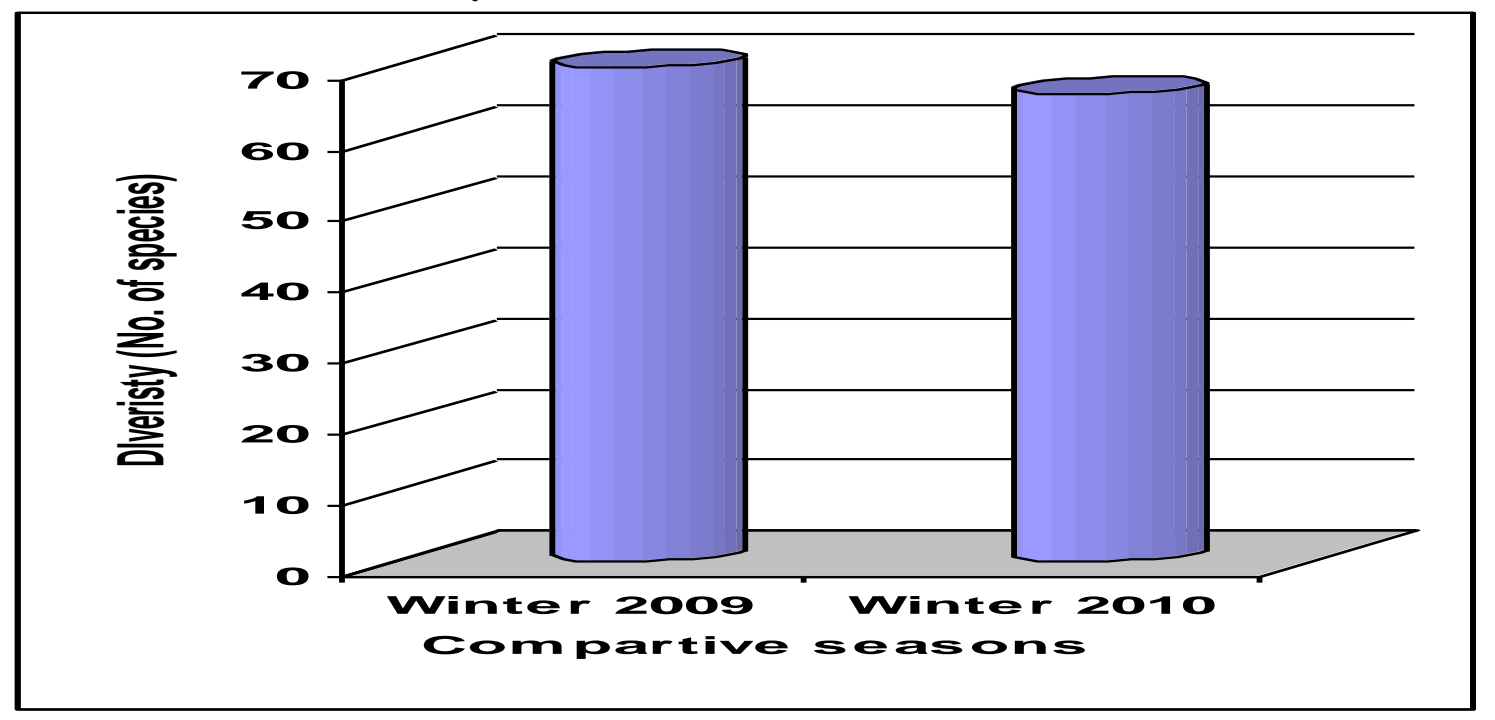

Figure (10): Copepod diversity in winter season between successive two years 2009 and 2010. 
The diversity of copepods inhabiting Egyptian Mediterranean waters was relatively homogeneous between the same seasons at successive two years (fig. 10). Copepods diversity were higher in winter 2009 (70 species) than winter 2010 (66 species). Farranula rostrata, Oithona nana and Clausocalanus arcuicornis were the highest abundant species in winter 2009. While, the main abundant species in winter 2010 were Oithona nana with an average abundance of $\left(68 \mathrm{ind} . / \mathrm{m}^{3}\right)$, Nannocalanus minor $\left(57 \mathrm{ind} . / \mathrm{m}^{3}\right)$ and Clausocalanus arcuicornis (49 ind. $\left./ \mathrm{m}^{3}\right)$.

\section{7- Ecological indices of copepods diversity in the Egyptian Mediterranean water:}

Figure (11) shows the different ecological indices of the recorded copepods diversity at different investigated sectors in the Egyptian Mediterranean water. It is clear from this table, the data showed very little variations at the different sectors for all ecological indices except at Marsa Matrouh which has great downhill in its species richness. The highest value of species richness occurred at Sidi Brani sector being 10.41, while the lowest value occurred at Marsa Matrouh sector being 7.8. The highest value of Shannon index was recorded at Sidi Brani sector being 3.79, while the lower value was recorded at Marsa Matrouh sector being 3.54 (fig., 11).

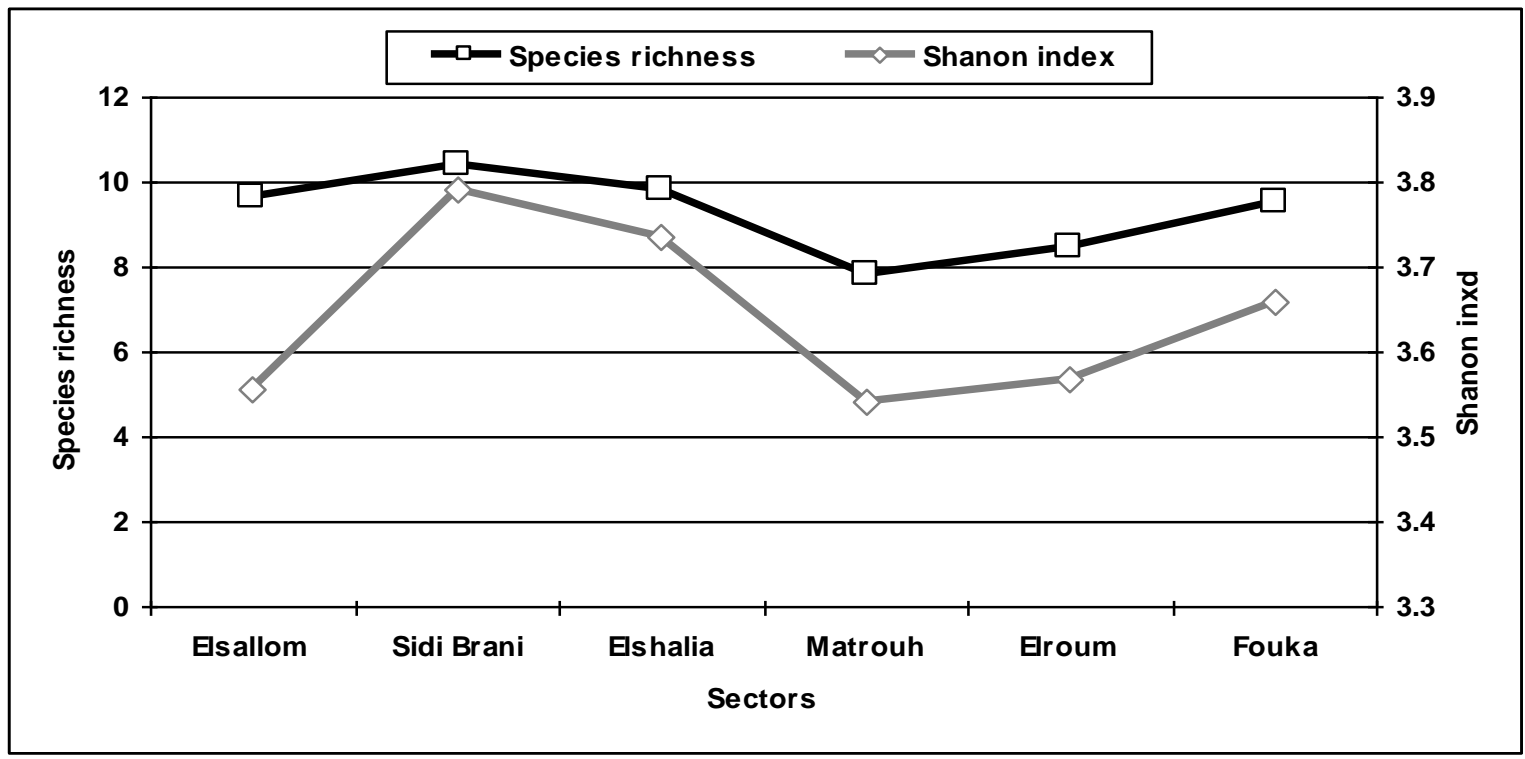

Fig. (11): The diversity indices for copepods species inhabiting the Egyptian Mediterranean water.

\section{DISCUSSION}

At the Egyptian Mediterranean, the percentage of copepods community in the present study (74.14\% of the total zooplankton) seem to be higher than that recorded by Hussein (1977 and 1997a,b), Dowidar et al., (1983), Aboul Ezz (1994), Abdel-Aziz (2002) and Zakaria (2006 and 2007a) with an average 71\%, 45.81\%, 57.79\%, 41\%, 29.2\%, 46.5\%, 27\% and $34.18 \%$, respectively. While, it was too less than the percentage recorded in the inshore waters of Mediterranean sea as indicated by Dowidar and El-Maghraby (1973), Nour ElDin (1987) and Abdel-Aziz and Aboul-Ezz (2003), who gave an average of 77\%, 83.5\% and 63-92.1\%, respectively.

The copepod population was gave raises a total of 129 species dominating by Oithona nana, Calocalanus pavo and Nannocalanus minor. The diversity of copepods in the present study was higher than previously recorded in the Egyptian Mediterranean water by ElMaghraby (1965); Dowidar and El-Maghraby (1970a) Hussein (1977 and 1997b); Nour El-Din (1987); Aboul Ezz (1994) and Abdel-Aziz and Aboul-Ezz (2003), who identified 75 
species, 83 species, 112 species, 37 species, 126 species, 23 species and 71 species. While, Dowidar and El-Maghraby (1970b and 1973) identified 132 and 167 copepod species respectively more diversified than the present study. The differentiation in abundance and diversity between the present and previous studies may be attributed to many reasons such as the difference of study sites along Egyptian Mediterranean cost; period and mode of collection, mesh size zooplankton net and climatic change which affect on planktonic organisms migration process. Different method of collection yielded different result as investigated by Abd El-Rahman (2005).

Fifty five copepods species were recorded for the first time in the Egyptian Mediterranean water, among them thirty two species were seem to be new record in the whole Mediterranean Sea for the first time. The magnitude of new recorded species of copepods in the present study seem to be resulted from differences in the collecting efforts, seasonality, area investigated and little attention that copepods received it in the Mediterranean Sea. Also, the increase in the number of copepods from the Egyptian Mediterranean water may be due to migration activity from other water systems to Mediterranean Sea. Egyptian part of Mediterranean Sea faced dramatic changes from two man-mad pathways, the Suez Canal which opened in 1869 and the construction of the Aswan High Dam in 1966 (Rizkalla, 1997). These changes in Mediterranean hydrology and Ecology were act as the principle factor in the migration of organisms between Mediterranean Sea and other ones. Kimor (1972); Por (1978) declared that the migration process is increasing from south toward the north of the Suez Canal particularly after the disappearance of hydrological barriers from the canal pathway and the increasing salinity in the hole Levantine Basin after the high Aswan Dam Event. These may be indicated that the increase of the recorded species percent in the IndoPacific, where many species may be migrated into Mediterranean from Indian and Pacific Oceans across Red Sea. Gomez (2006) and Zaafa et al. (2012) contributed the increase of zooplankton migration in Mediterranean Sea from Atlantic Ocean to continuous replenishment of the plankton populations by the inflow of Atlantic water through the Strait of Gibraltar.

Kovalev (2006) and Dorgham et al. (2012) presumed that the scientific evidence accumulated on the zooplankton migrations from the Red Sea to the Mediterranean through the Suez Canal was concluded of some of the zooplankton, e.g. copepods as immigrants from the Red Sea, may in fact come from the Atlantic. The assumption is based on the fact that these organisms occur both in the eastern and the western Mediterranean and inhabit the Atlantic Ocean, the Gibraltar Strait and the adjoining seawater, but are absent from the Suez Canal. It can be presumed that some zooplankton species widespread in the world ocean entered the Mediterranean through the Gibraltar Strait and the Suez Canal. They improved again that the Red Sea species play an important role in formation of the flora and fauna of the eastern Mediterranean, especially along the southeastern coast. After the dredging and widening of the Suez Canal and the construction of the Aswan dam that regulates the Nile inflow, the significance of Red Sea immigrant organisms has increased.

Zooplankton distribution and migration is affected by both abiotic (Marques et al., 2007a,b) and biotic parameters (e.g. predation, competition) (Isari et al., 2007). In the Eastern Mediterranean, dramatic medications of the deep and intermediate circulation that started in the late 1980s have been related to a transient effect of climatic changes in the Ionian Sea (Mazzocchi et al., 2003) and Adriatic Sea (Kamburska and Fonda-Umani, 2006 and Mikus et al., 2013). Some monotonous trends in the decadal changes observed in the Mediterranean marine ecosystem have been however interpreted as more affected by anthropogenic than climate forcing (Duarte et al., 1999). In the Levantine Basin, anthropogenic factors such as the Aswan High Dam and deepening of Suez Canal have induced the migration of planktonic fauna from the Red Sea, which was further enhanced by 
the observed rise in temperature and salinity (Lakkis and Zeidane, 2004). Salinity and temperature are the main factors influencing zooplankton distribution, which is thus directly influenced by freshwater inputs (Marques et al., 2006).

In addition, the maritime activities in the Mediterranean Sea during the recent decades may be contributed in change of diversity of the copepods in the area. Ballast water can be playing an important role in copepods biodiversity change; it transfers species between different environments. Some of new recorded copepods species may be found in the investigated area by ballast water. The Mediterranean Sea has many ports open for international shipping. The ongoing transfer of harmful organisms by shipping, especially via ballast water transport, may result in a change of biodiversity (David et al., 2007).

In regards to, the temporal distribution of copepods indicated the highest abundance and diversity were occurred in spring season and the low values in winter, these agree with Abdel-Aziz and Aboul Ezz (2003). Aboul Ezz (1994) in Mediterranean coast of Port Said, recorded the highest copepods abundance in August and the lowest in January and February, while Nour El-Din (1987) and Hussein (1997b) found its highest density in autumn. Hussein (1977) and Zakaria (2007a) who indicated other seasons for copepods massive production.

The spatial distribution of copepods indicated that the eastern sectors of the Egyptian Mediterranean coast harbored more abundance than the western ones. While, the diversity of copepods were higher at the western sectors than the eastern ones. In contrast to this result, Hussein (1977) found that copepods abundance at Mediterranean water was decreased toward east. Abdel-Aziz and Aboul-Ezz (2003) said that the western side of the Mediterranean Sea was characterized by higher diversity than the eastern side may by attributed to effect it by land based effluents discharged to the sea from the coastal lakes and the River Nile. Marsa Matrouh was the poorest abundant and diversified sector, it resemble to that founded by Hussein (1977).

Regarding to the diversity indexes that are used as a measure of ecological "health" or stability of the biotic communities. The present data of diversity indexes revealed that the study area of the Mediterranean Sea has a great variety of planktonic copepods species (high diversity). The species indexes values typically indicated the species diversity and abundance variation among investigated sectors. (Bojanic et al., 2012) found that the species richness (S) was positively related to overall zooplankton abundance on a temporal scale, but the strength of that relation was negatively related to increased trophic state. zooplankton abundance and species dominance increased proportionally with increased trophic state. He concluded that species richness was positively related to overall abundance temporally and was also affected by environmental trophic state. The species diversity index can increase without an increase in taxon number if evenness increases (Wen et al., 2011).

The result indicates that the abundance and diversity of copepods inhabiting at Mediterranean Sea was homogeneous between the same seasons at successive two years. Against these results El-Shabrawy and Dumont (2003) stated that the seasonal influence is represented by the yearly amplitude of water temperature. In this framework, El-Naggar (2008) found the same present result when compare the diversity and abundance of rotifers in the same month for successive two years at Damietta Nile Branch. The increase of copepod abundance and diversity in winter 2010 than winter 2009, and appear and disappear of some species among two seasons may be attributed to climatic change Phenomenon. Irogoien $\boldsymbol{e t}$ al., (2004) confirmed that the zooplankton response to changes in the ocean environment. Mackas et al., (2001) stated that the zooplankton populations have the potential to respond to the seasonal changes in environmental conditions. Zooplankton may serve as sentinel taxa that reflect changes in marine ecosystems by providing early indications of a biological response to climate variability (Hays et al., 2005). Goncalves et al., (2012) studied responses 
of Copepoda life-history stages to climatic variability in southern-european a temperate estuary and stated that the changes of climate affect on community structure, Moreover, a severe drought was responsible for the dominance of marine species in estuaries environment.

\section{REFERENCES}

Abd El-Rahman, N.S., (2005): The immigration progress of planktonic copepoda across the Suez Canal, Egypt. Egy. J. Aqu. Biol.. \& Fish., 9 (3): 59-82.

Abdel-Aziz, N.E., (1997): Zooplankton production along Egyptian Medirerranean coast at Alexandria with special reference to life history of one copepod species. Ph. D. Thesis, Fac. of Sci, Mansoura Univ., 384p.

Abdel Aziz, N.E., (2002): Impact of water circulation and discharge wastes on zooplankton dynamics in the Western Harbour of Alexandria, Egypt. Egy. J. Aqu. Biol. and Fish., $6(1): 1-21$.

Abdel Aziz, N.E. and Aboul-Ezz, S.M., (2003): Zooplankton community of the Egyptian Mediterranean coast. Egy. J. Aqu. Biol. \& Fish, 7 (4):91-10.

Aboul-Ezz, S.M., (1994): Distribution of zooplankton communities in the Swash zone along the Mediterranean Coast of Port-Said (Egypt). Bull. Nat. Inst. Ocean. \& Fish. A.R.E., 20 (1): 99-128.

Al-Mutairi, H. A., (2009): Non-calanoid copepods at the Bermuda Atlantic time-series (BATS) station: Community structure and ecology, 1995-1999. PhD. Thesis, College of Marine Sci., Univ. of S. Florida, 235 pp.

Ananth, S. and P. Santhanam, (2011): Laboratory culture and biochemical profile of marine copepod, Macrosetella gracilis (Dana). Aqu, 12: 49-55.

Ananthi, P., P. Santhanam, R. Nandakumar, S. Ananth, K. Jothiraj, S. Dineshkumar, B. Balaji Prasath and T. Jayalakshmi, (2011): Production and utilization of marine copepods as live feed for larval rearing of shrimp Penaeus monodon with special emphasis an astaxanthin enhancement. J. Natural Sci., 11: 494-503.

Bennett, William A. (2005): Critical Assessment of the Delta Smelt Population in the San Francisco Estuary. San Francisco Estuary and Watershed Sci.3.2:1-75.

Bojanic, N., Oljavidjaki, Solic, M., Krstulovic, N., Brautovic, I., Matijevic, S., Kuspilic, G., Sestanovic, S., Gladan, Z.N., and Marasovic, I., (2012): Community structure and seasonal dynamics of tintinnid ciliates in Kastela Bay (middle Adriatic Sea). J. OF Plank. Res., 34 (6): 510-530

Boltovskoy, D. (ed.) (1999): South Atlantic Zooplankton. Vols. 1 \& 2. Backhuys Publishers, Leiden, the Netherlands, $1706 \mathrm{pp}$.

Cassiano, E. J., C. L. Ohs, C. R. Weirich, N. E. Breen and A. L. Rhyne, (2011): Evaluation of larval Florida pompano, Trachinotus carolinus, fed nauplii of the calanoid copepod Pseudodiaptomous pelagicus. N. American J. of Aqu., 73: 114-123.

Conway, D.V.P., White, R.G., Hugues-Dit-Ciles, J., Gallienne, C.P. and Robins, D.B. (2003): Guide to the coastal and surface zooplankton of the south-western Indian Ocean, Occasional Publication of the Marine Biological Association of the United Kingdom, No. 15, Plymouth, UK, 367 pp. 
David, M., Gollasch, S., Cabrini, M., Perkovic, M., Bosnjak, D., and Virgilio, D., (2007): Results from the first ballast water sampling study in the Mediterranean Sea - the Port of Koper study. Mar. Pollution Bull. 54: 53-65

Dorgham, M. M., Elsherbiny, M. M. and Hanafi M. H., (2012): Vertical distribution of zooplankton in the epipelagic zone off Sharm El-Sheikh, Red Sea, Egypt. Oceanologia, 54 (3): 473-489.

Dowidar, N.M. \& El-Maghraby A.M., (1970a): The neritic zooplankton of the southeastern Mediterranean at Alexandria. I. Distribution and ecology of the zooplankton organisms with special reference to Copepoda. Bull. Nat. Inst. Ocean.\& Fish., Egy., 1: 225-273.

Dowidar, N.M. \& El-Maghraby A.M., (1970b): The neritic zooplankton of the southeastern Mediterranean at Alexandria. II. Consideration of the total zooplankton species community. Bull. Nat. Inst. Ocean.\& Fish., Egy., 1: 275-303.

Dowidar, N.M. and El-Maghraby, A.M., (1973): Notes on the occurencc and distribution of some zooplankton species in the Mediterranean waters of UAR, Rapp. Comm. Int. Mer Medit., Monaco, 21 (8): 521-525.

Dowidar, N.M., Khalil A.N., El-Maghraby, A.M. and El-Zawawy, D.A., (1983): Zooplankton composition of the Eastern Harbour of Alexandria, Egypt. Rapp. Comm.. Int. Mer. Medi., 28 (9): 195-196.

Duarte, C.M., Agust, S., Kennedy, H., and Vaque, D., (199): The Mediterranean climate as a template for Mediterranean marine ecosystems: the example of the northeast Spanish littoral, Prog. Ocean., 44, 245-270.

Edmondson, W.T.; Ward H.B. \& Whipple G.C., (1959): Fresh water biology, 2nd ed. John Wiley and Sons Ins. New York and London, XX, 1248p.

El-Gindy, A.A.H., Abdel Aziz, N.E., Dorgham, M.M., (2008): Statistical and fourier analysis of cyclic changes of zooplankton abundance in the Eastern harbour of Alexandria. Indian J. of Mar. Sci., 37 (3): 279-290.

El-Maghraby, A.M., (1965): The occurrence and distribution of pelagic copepods in the eastern Mediterranean off the Egyptian coast. General fish. Council for the Mediterranean proc. Tech. Paper No. 8, FAO.

El-Naggar, H.A., (2008): Distribution and abundance of planktonic rotifers in aquatic habitats of the Nile Delta, Egypt. M.Sc. Thesis, Fac. Sci., Al-Azhar Univ. Egy., $216 \mathrm{p}$.

El-Shabrawy G.M. and Dumont H. J., (2003): Spatial and seasonal variation of the zooplankton in the coastal zone and main khors of Lake Nasser (Egypt). Hydrob., 491: 119-132.

Gomez, F., (2006): Endemic and Indo-Pacific plankton in the Mediterranean Sea: A study based on dinoflagellate records, J. Biogeogr., 33: 261-270.

Gonçalves, A.M.M., Miguel Â. Pardal, Sónia C. Marques, Susana Mendes, María J. Fernández-Gómez, María P. Galindo-Villardón, and Ulisses M. Azeiteiro, (2012): Responses of Copepoda life-history stages to climatic variability in a southern-European temperate estuary. Zoological Stu. 51(3): 321-335.

Halim.Y., (1990): On the potential migration of Indo-Pacific plankton through the Suez Canal. Bull Inst. Ocean. Monaco, 7: 11-27. 
Hays, G.C., Richardson, A.J. and Robinson, C., (2005): Climate change and marine plankton. Trends in Ecol. and Evol. 20: 337-344.

Hemaida, H. A. E., Goma, R. H., Shakweer, L. M., (2008): Chemical evaluation for weastern coast of Mediterranean Sea in Egypt. Bull. of high Inst. of public health, 38 (1): 91-109.

Hussein, M.M., (1977): A study of the zooplankton in the Mediterranean waters off the Egyptian Coast during 1970-1971 with special reference to copepods. M.Sc. Thesis, Fac. of Sci., Alex. Univ., 269p.

Hussein, M.M., (1997a): Distribution of zooplankton assemblages in El-Mex Bay, Alexandria, Egypt. Bull. Nat. Inst. Oceanogr. \& Fish., ARE, 23: 217-240.

Hussein, M.M., (1997b): Zooplankton community structure in the offshore neritic area of Alexandria waters, Egypt. Bull. Nat. Inst. Ocean. \& Fish., ARE, 23: 241-265.

Irogoien, X., Huisman, J., and Harris R., (2004): Global biodiversity patterns of marine phytoplankton and zooplankton. Nature 429: 863-867.

Isari, S., Psarra, S., Pitta, P., Mara, P., Tomprou, M.O., Ramfos, A., Somarakis, S., Tselepides, A., Koutsikopoulos, C. and Fragopoulu, N., (2007) Differential patterns of mesozooplankters' distribution in relation to physical and biological variables of the northeastern Aegean Sea (Eastern Mediterranean). Mar. Biol., (151): 1035-1050.

Kamburska, L., Fonda-Umani, S., (2006): Long-term copepod dynamics in the Gulf of Trieste (Northern Adriatic Sea): recent changes and trends. Climate Res. 31: 195203.

Kimor, B., (1972): The Suez Canal as a link and a barrier in the migration of plankton organisms. Israel- J. Zoo., 21: 391-403.

Kovalev, A.V., (2006): On the problem of Lessepsian migrations of zooplanktonic organisms. Medit. Mar. Sci., 7 (2): 67-71

Lakkis, S. and Zeidane, R., (2004): Exotic species and lessepsian migration of plankton in Lebanese waters, Levantine Basin, Eastern Mediterranean. Rapp. Comm. Int. Mer Medit. 37, 384.

Lancelot, C., Staneva, J., Van Eeckhout, D., Beckers, J.M., Stanev, E., (2002): Modelling the Danube-influenced north-western continental shelf of the Black Sea. Part II: Ecosystem response to changes in nutrient delivery by the Danube River after its damming in 1972 . Tuar. Cost. Shelf Sci., 54: 473-499.

Mackas, D.L., Thomson, R.R., and Calbraith, M., (2001): Changes in the zooplankton community of the British Columbia continental margin, 1985-1999, and their covariation with oceanographic conditions. Can. J. Fish. Aquat. Sci., 58: 685702 .

Margalef. R., 1968. Perspectives in Ecological Theory. Univ. of Chic. Press, Chic., IL, 111pp. Marques, S.C., Azeiteiro, U.M., Marques, J.C., Neto, J.M. and Pardal, M.A., (2006): Zooplankton and ichthyoplankton communities in a temperate estuary: spatial and temporal patterns. J. of Plan. Res., 28: 297-312.

Marques, S.C., Azeiteiro, U.M., Martinho, F. and Pardal, M.A., (2007a): Climate variability and planktonic communities: the effect of an extreme event (severe drought) in a southern European estuary. Estuarine, Coastal and Shelf Sci., 73: 725-734. 
Marques, S.C., Pardal, M.A., Pereira, M.J., Gonçalves, F., Marques, J.C. and Azeiteiro, U.M., (2007b): Zooplankton distribution and dynamics in a temperate shallow estuary. Hydrobio., 587: 213-223.

Mazzocchi, M.G., Nervegna, D., D’Elia, G., Di Capua, I., Aguzzi, L., Boldrin A., (2003): Spring zooplankton communities in the epipelagic Ionian Sea in relation to the Eastern Mediterranean Transient. J. of Geophysical Res. Oceans108 (C9): article No. 8114.

Mikus, J., Batistic, M., Krsinic, F., Pecarevic, M., Lucic, D., (2013): The Structure of Zooplankton Population in the Jabuka Pit Area (Eastern Mediterranean). "Nase more". 60 (1-2): 40-47

Nour El-Din, N.M., (1987): Ecology and distribution of pelagic copepods in the Mediterranean waters of Egypt. M. Sc. Thesis, Fac. of Sci., Alex. Univ., 213p.

Olivotto, I., N. E. Tokle, V. Nozzi, L. Cossignani and O. Carnevali. (2010): Preserved copepods as a new technology for the marine ornamental fish aquaculture: A feeding study. Aquac., 308: 124-131.

Por, F.D., (1978): Lessepsian migration. The influx of the Red sea Biota into the Mediterranean by way of the Suez Canal. Ecological Studies. Spring-Verlag, Berlin, 228 p.

Rizkalla, S.I., (1997): New recorded of lessepsian fishes found in the Egyptian Mediterranean waters. Proc. of the $7^{\text {th }}$ Inter. Conf. on Envi. Prot. Is a Must., Alexandria, Egypt. Organized by N.I.O.F. and I.S.A., 461-470.

Rose, M., (1933): Copepods pelagiques. In Faune de France, pp. 1-374. Paris: Le Chevalier.

Said, M.A. and Eid, F.M., (1994): A quantitative analysis of south-eastern Mediterranean water masses. Acta Ocean. Syn., 3 (2): 203-212.

Schipp, G., (2006): The use of calanoid copepods in semi-intensive, tropical marine fish larviculture. In: Cruz-Suárez, L.E., Rique-Marie, D., Tapia-Salazar, M., NietoLópez, M.G., Villareal-Cavazos, D.A., Puello-Cruz, A.C., García-Ortega, A. (Eds.), Avances en Nutrición Acuícola VIII. 8th Int. Symp. Aqu. Nutrition. Univ. Autón. Nuevo León, Mont. pp. 84-94.

Shannon, C. \& Weaver W., (1963): The mathematical theory of communications, Univ. Illinois Press, Urban, 125p.

Steinberg, DK, Goldthwait, SA, Hansell, D.A., (2002): Zooplankton vertical migration and the active transport of dissolved organic and inorganic nitrogen in the Sargasso Sea. Deep-Sea Res. Part IOceanographic Res. Papers 49:1445-1461.

Tregouboff, G. \& Rose, M., (1957): Manual de planctologie Mediterranee. I- (Texte), 587pp. II- (Fig.), 207pl. C.N.R.S., Paris.

Walter, T.C. and Boxshall, G.A., (2008): World of Copepods database. Available online at http://www.marinespecies.org/copepoda.

Wen, X.L., Xi, Y.L., Qian, F.P., (2011): Comparative analysis of rotifer community structure in five subtropical shallow lakes in East China: role of physical and chemical conditions. Hydrobio., 661: 303-316 
Zaafa, A., Ettahiri, O., Berraho, A., Elkhiati, N., Somoue, L., Zizah, S., Ramdani, M., Blaghen, M., and Flower, R., (2012): A comparative study of marine zooplankton communities in the Tangier and M'Diq (Gibraltar strait) regions. Hydroécol. Appl.

Zakaria, H.Y., (2006a) Zooplankton community in the Eastern Harbour of Alexandria, Egypt. Egy. J. of Aqu. Res., 32 (Special Issue): 196-209.

Zakaria, H.Y., (2006b): The zooplankton community in the Egyptian Mediterranean waters: A Review. ACTA ADRIAT., 47 (2): 195-206.

Zakaria, H.Y., (2007a): On the distribution of zooplankton assemblages in Abu Qir Bay, Alexandria, Egypt. Egy. J. of Aqu. Res., 33 (1): 238-256.

Zakaria, H.Y., (2007b): Zooplankton abundance and biomass in the coastal waters of Alexandria, Egypt. Proceedings of the Eighth International Conference on the Mediterranean Coastal Environment, MEDCOAST 07, E. Ozhain (Editor), 13-17 November 2007, Alex, Egy., Part 1: 537-548.

Zakaria, H.Y., Radwan, A.A. and Said, M.A., (2007): Influence of salinity variation on zooplankton community in El-Mex Bay, Alexandria, Egypt. Egy. J. of Aqu. Res., 33 (3): 52-67.

التوزيع الزمني، المكاني والهيدروغرافي لمجدافيات الأرجل بطول غرب الساحل المصري للبحر الأبيض المتوسط.

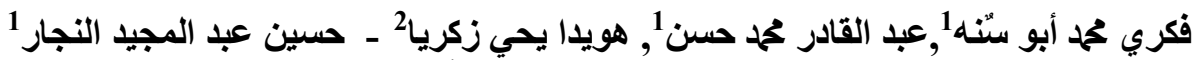

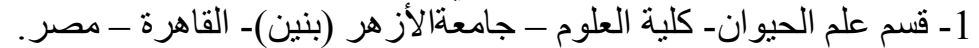

$$
\begin{aligned}
& \text { 2- المعهد القومي لعلوم البحار و المصايد ـ الإسكندرية ـ مصر. }
\end{aligned}
$$

بطول غرب الساحل المصـري للبحر المتوسط, جُمعت عينـات مجدافيات الأرجل خـلال أربع موسـ

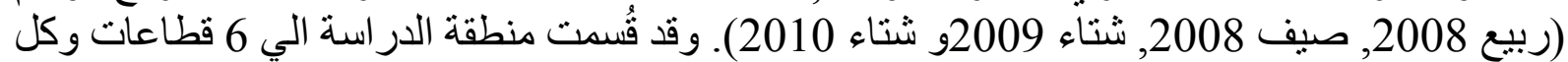

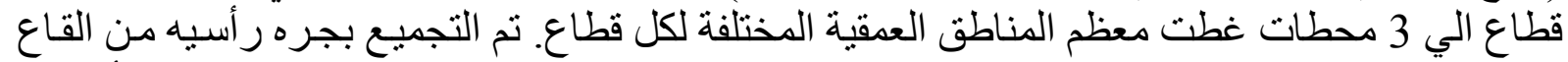

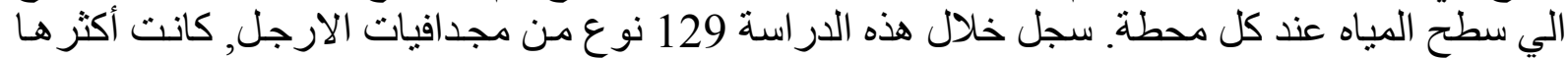

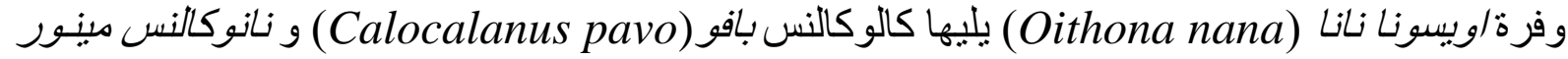
(Nannocalanus minor) المو اسم الأخري. بمقارنة وفرة وتنوع مجدافيات الأرجل بين نفس الموسم لسنتن متعاقبتين وجد انها كانت

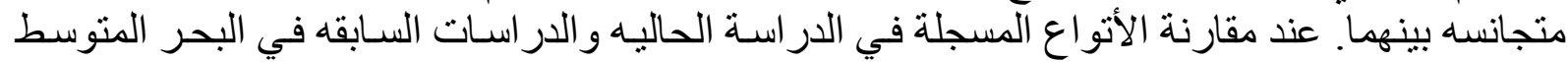

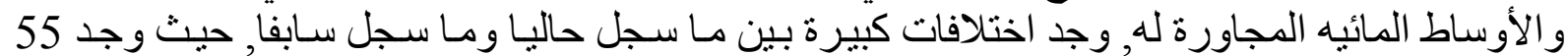

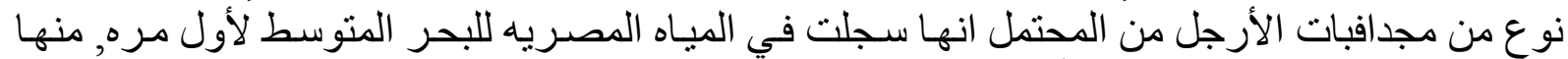
32 نوع قد يكون انها للمره لأول تُسجل في مياه البحر المتوسط ككل. 